Provided for non-commercial research and education use. Not for reproduction, distribution or commercial use.

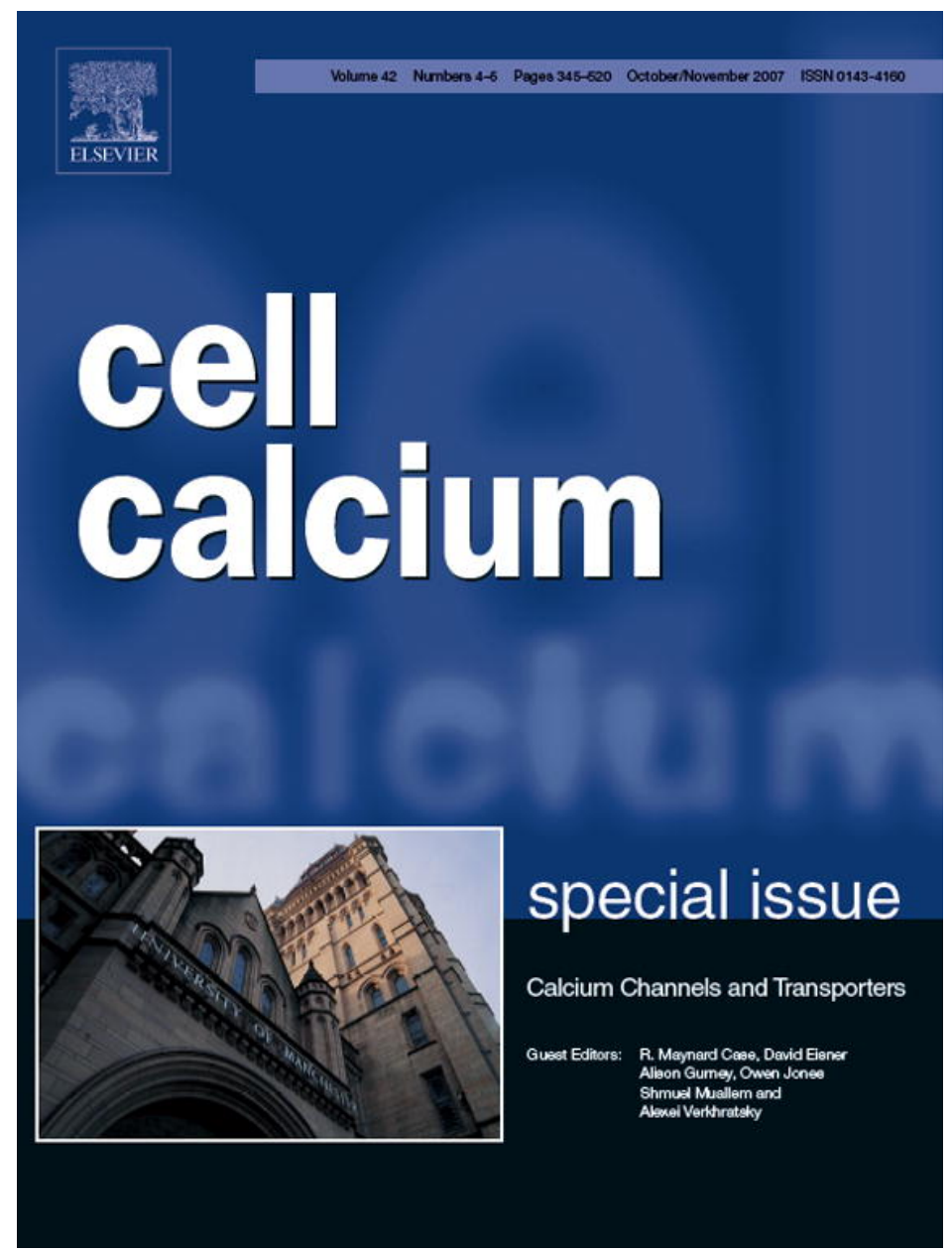

This article was published in an Elsevier journal. The attached copy

is furnished to the author for non-commercial research and education use, including for instruction at the author's institution, sharing with colleagues and providing to institution administration.

Other uses, including reproduction and distribution, or selling or licensing copies, or posting to personal, institutional or third party websites are prohibited.

In most cases authors are permitted to post their version of the article (e.g. in Word or Tex form) to their personal website or institutional repository. Authors requiring further information regarding Elsevier's archiving and manuscript policies are encouraged to visit: 


\title{
L-type calcium channels in adrenal chromaffin cells: Role in pace-making and secretion
}

\author{
A. Marcantoni, P. Baldelli ${ }^{1}$, J.M. Hernandez-Guijo ${ }^{2}$, \\ V. Comunanza, V. Carabelli, E. Carbone* \\ Department of Neuroscience, NIS Center of Excellence, CNISM Research Unit, Corso Raffaello 30, 10125 Torino, Italy
}

Received 21 April 2007; accepted 29 April 2007

Available online 11 June 2007

\begin{abstract}
Voltage-gated L-type (Cav1.2 and Cav1.3) channels are widely expressed in cardiovascular tissues and represent the critical drug-target for the treatment of several cardiovascular diseases. The two isoforms are also abundantly expressed in neuronal and neuroendocrine tissues. In the brain, Cav1.2 and Cav1.3 channels control synaptic plasticity, somatic activity, neuronal differentiation and brain aging. In neuroendocrine cells, they are involved in the genesis of action potential generation, bursting activity and hormone secretion.

Recent studies have shown that Cav1.2 and Cav1.3 are also expressed in chromaffin cells but their functional role has not yet been identified despite that L-type channels possess interesting characteristics, which confer them an important role in the control of catecholamine secretion during action potentials stimulation. In intact rat adrenal glands L-type channels are responsible for adrenaline and noradrenaline release following splanchnic nerve stimulation or nicotinic receptor activation. L-type channels can be either up- or down-modulated by membrane autoreceptors following distinct second messenger pathways. L-type channels are tightly coupled to BK channels and activate at relatively low-voltages. In this way they contribute to the action potential hyperpolarization and to the pace-maker current controlling action potential firings. L-type channels are shown also to regulate the fast secretion of the immediate readily releasable pool of vesicles with the same $\mathrm{Ca}^{2+}{ }_{-}$ efficiency of other voltage-gated $\mathrm{Ca}^{2+}$ channels. In mouse adrenal slices, repeated action potential-like stimulations drive L-type channels to a state of enhanced stimulus-secretion efficiency regulated by $\beta$-adrenergic receptors.

Here we will review all these novel findings and discuss the possible implication for a specific role of L-type channels in the control of chromaffin cells activity.

(C) 2007 Elsevier Ltd. All rights reserved.
\end{abstract}

Keywords: Cav1.2 and Cav1.3 calcium channels; Pace-maker current; $\beta$-Adrenergic modulation; Exocytosis; Vesicle release; Capacitance increase

\section{Introduction}

Voltage-gated L-type $\mathrm{Ca}^{2+}$ channels are widely expressed in many tissues and control a number of $\mathrm{Ca}^{2+}$-dependent

\footnotetext{
* Corresponding author. Tel.: +39011 670 7786; fax: +39 0116707708 .

E-mail addresses: pietro.baldelli@unige.it (P. Baldelli), jesusmiguel.hernandez@uam.es (J.M. Hernandez-Guijo), emilio.carbone@unito.it (E. Carbone).

${ }^{1}$ Present address: Department of Experimental Medicine, Viale Benedetto XV 3, 16132 Genova, Italy.

2 Present address: Department of Pharmacology \& Therapeutics, Universidad Autónoma de Madrid, Av. Arzobispo Morcillo 4, 28029 Madrid, Spain.
}

responses in electrically excitable cells. They include several subtypes containing the pore-forming $\alpha_{1 \mathrm{~S}}, \alpha_{1 \mathrm{C}}, \alpha_{1 \mathrm{D}}$ and $\alpha_{1 \mathrm{~F}}$ subunits (Cav1.1, Cav1.2, Cav1.3 and Cav1.4) with different structure-function characteristics but common blockers: dihydropyridines (DHPs), phenylalkylamines, benzothiazepines [1]. Members of the L-type channel family activate upon membrane depolarization and represent one of the central pathways by which intracellular $\mathrm{Ca}^{2+}$ can be raised in neuronal and neuroendocrine cells $[2,3]$. Elevation of intracellular $\mathrm{Ca}^{2+}$ represents the triggering event of hormone secretion and cell differentiation [4,5], and thus the right characterization of L-type channels functioning and their modulation helps understanding 
key issues of neuroendocrine cells activity and neuronal functioning.

L-type channels possess several properties that are important for the control of neuroendocrine cell activity. The first is their high density of expression and main role in the control of hormone secretion in a variety of cells. L-type channels have indeed wide control of insulin release in pancreatic $\beta$-cells $[6,7]$, pituitary glands [8] and catecholamine in a number of chromaffin cell species [9-11]. In addition to this, their density can be either up- or down-regulated by various stimuli, including: hypoxia [12], growth factors [13], hormones [14] and neurotransmitters [15]. The second property of L-type channels is that their gating can be effectively inhibited or potentiated by neurotransmitters coupled to membrane receptors (see [16,17] for reviews). Among the many modulatory pathways, two appear of particular interest for neuroendocrine cells because of their autocrine nature: the membrane-delimited $\mathrm{G}$ proteindependent inhibition and the remote cAMP/PKA-mediated potentiation [16,17]. In chromaffin cells, both pathways are activated by autoreleased neurotransmitter molecules and produce opposing effects of comparable entity [18]. A third property of L-type channels of particular interest is their low-threshold of activation with respect to the other high-threshold channels (N, P/Q, R), which is remarkably low for the Cav1.3 isoform [19], conferring to it the ability of pace-making cells [20]. This is true also in chromaffin cells that express both Cav1.2 and Cav1.3 [21-24] and, thus, an open question is how much the two channels contribute to the genesis of action potential firings and how much the different gating modulations induced by membrane receptors reflect a different action on these two channel types. A final interesting point worth being underlined is the tight coupling between $\mathrm{Ca}^{2+}$-activated $\mathrm{K}^{+}$ channels and L-type $\mathrm{Ca}^{2+}$ channels [25,26], which condition the shaping of action potential and the frequency of action potential firing. Strict co-localization of BK and L-type channels as postulated for the rat chromaffin cells (RCCs) implies a further direct control of L-type channels on $\mathrm{Ca}^{2+}$ influx through other voltage-gated $\mathrm{Ca}^{2+}$ channels.

In our view these peculiar properties of L-type channels are so strategic for the activity of chromaffin cells that their full understanding will help solving critical issues concerning the physiology and pharmacology of catecholamine release during extreme electrical stimulation of the adrenal gland, as it occurs during basal or stressful body conditions. This review aims at clarifying some of the peculiarities that Ltype channels possess and that are linked to the regulation of intracellular $\mathrm{Ca}^{2+}$ required for triggering vesicle exocytosis and catecholamine release. The recent observations that $\mathrm{Ca}^{2+}$ entry through voltage-gated $\mathrm{Ca}^{2+}$ channels can be tightly linked to the mitochondria and endoplasmic reticulum $\mathrm{Ca}^{2+}$ buffering system [27,28] may be one of the new arguments that we have to face in the near future (see [11] for e review).

\section{The direct and remote L-type channel modulation in RCCs}

L-type channel modulation is largely heterogeneous and covers a broad spectrum of molecular mechanisms. A major subdivision should include the signaling pathways that are either voltage-dependent or voltage-independent. Among the first class should be mentioned: (1) the voltagedependent facilitation producing L-type current increases following strong and long lasting pre-pulses described in cardiac, neuronal and neuroendocrine cells [29-31] and, (2) the voltage-dependent and cAMP-mediated phosphorylation, capable of facilitating the L-type channel expressed in skeletal muscle, neuronal and neuroendocrine cells by a fast phosphorylation reaction favored by strong depolarizations [32-34] and by the close proximity of PKA to the channel [35]. Both modulatory pathways have been described in past review articles $[16,17]$. Here, we will focus on the voltage-independent forms of neuroendocrine L-type channel modulation that include the direct inhibition of L-type channels by $\mathrm{G}$ protein-coupled receptors (GPCRs) and the cAMP-mediated potentiation that have autocrine origins and can be back regulated by the material released during secretion.

\subsection{Direct inhibition of L-type channels by $G$ proteins}

Neuronal and neuroendocrine L-type channels are effectively inhibited by neurotransmitters through GPCRmediated pathways. In most cases the inhibition is V-independent but there are examples in which the neurotransmitter has no action [36-38] or the inhibition is even $\mathrm{V}$-dependent, resembling that of $\mathrm{N}$ - and P/Q-type channels (see [11]). The depression causes 20-60\% inhibition of the current and there is no delay of L-type channel activation $[15,18,39,40]$. In Table 1 of ref [23] are listed a number of papers showing evidence for a $\mathrm{V}$-independent GPCR-mediated inhibition of L-type $\mathrm{Ca}^{2+}$ currents in neurons and neuroendocrine cells to which should be added the recently reported effect of muscarinic agonists on sympathetic neurons [41]. This latter further broaden the number of cell preparations in which the inhibition of L-type channels occurs: sensory, peripheral and central neurons, as well as $\beta$-pancreatic, chromaffin, adrenal glomerulosa and pituitary cells.

In the chromaffin cells of adrenal medulla, the neurotransmitter-mediated inhibition of L-type channels is fast and mainly $\mathrm{V}$-independent. The process is triggered by the same neurotransmitters released by the chromaffin granules (ATP, opioids and catecholamines) and produces a scaling down of the current amplitude [15]. The action is visible at the macroscopic and microscopic current levels [40] and is mimicked by ATP, $\mu / \delta$-opioid agonists (DAMGO and DPDPE), adrenaline (A) and noradrenaline (NA) when applied directly on RCCs pre-treated with $\omega$-CTx-GVIA and $\omega$-Aga-IVA to block N- and P/Q-currents (exogenous inhi- 
bition). It is interesting to notice that in bovine chromaffin cells (BCCs) and RCCs [15,39] the L-type current changes its amplitude depending on the flow conditions of cell perfusion. In "stop-flow" conditions the current is about half of the size recorded during rapid flow in which the secreted material is quickly cleared off. Facilitatory pre-pulse to $+100 \mathrm{mV}$ are ineffective in recovering part of the depression, indicating that L-type channel inhibition by neurotransmitters is autocrine and acts as negative feedback to control $\mathrm{Ca}^{2+}$ fluxes and neurotransmitter release in secretory cells (endogenous inhibition).

An important issue concerning the V-independent autocrine inhibition of L-type channels is whether the mechanism requires a diffusible second messenger or is direct (membrane-delimited) on the target channel. A direct action of $G_{i, o}$ proteins on L-type channels is already suggested by the fast onset ( $\tau_{\text {on }} 0.75 \mathrm{~s}$ ) and offset ( $\tau_{\text {off }} 3 \mathrm{~s}$ ) of the inhibition during rapid application and withdrawal of neurotransmitters to RCCs [15]. However, the most convincing evidence for a direct action comes from single channel studies in which the $\mathrm{G}_{\mathrm{i}, \mathrm{o}}$ protein-dependent inhibition of L-type channels is shown to be autocrine and fully defined in cell-attached micropatches $[40,42]$.

\subsection{Remote potentiation of L-type channels by the cAMP/PKA pathway}

Cav1.2 channel activity can be effectively potentiated by $\beta$-adrenergic stimulation, direct adenylate cyclase activation or application of membrane diffusable forms of cAMP and is not confined to cardiac tissues [43-45]. Effective cAMP/PKA-mediated phosphorylations leading to an
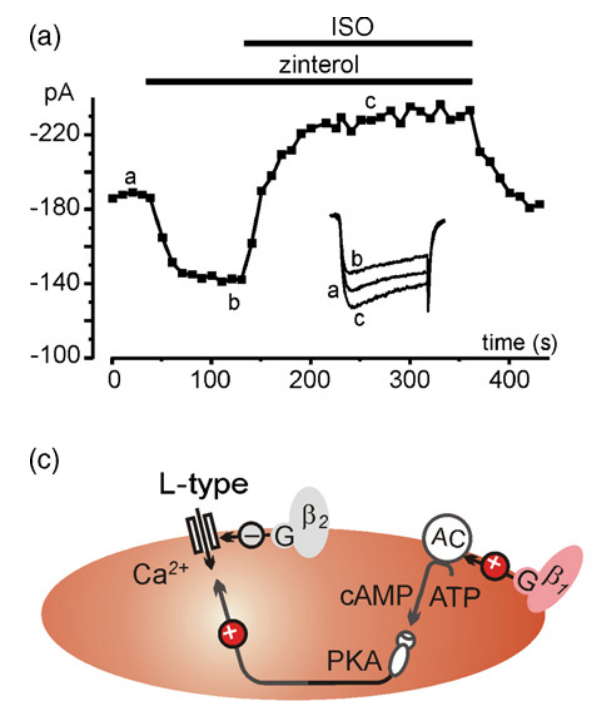

increased L-type current have been reported also in central neurons [46], mouse pancreatic $\beta$-cells $[47,48]$, BCCs [40] and RCCs [18]. In BCCs, application of cAMP causes a markedly increased probability of opening which results in an increased L-type channel activity mainly due to a decrease of channel closed times and number of null sweeps rather than an increase of mean open times [40]. The cAMPmediated potentiation is prevented by the PKA selective inhibitor $\mathrm{H} 89$ and proceeds regardless of the presence of the $\mathrm{G}_{\mathrm{i}, \mathrm{o}}$ protein-mediated inhibition. In RCCs the cAMP/PKAinduced potentiation of L-type channels is mediated by $\beta_{1}$-adrenergic receptors $\left(\beta_{1}-\mathrm{ARs}\right)$, which increase the $\mathrm{Ca}^{2+}$ current amplitudes and catecholamine release in an autocrine mode. $\beta_{1}$-ARs stimulation in RCCs $[17,18]$ possesses all the features of the remote action induced by the cAMP/PKA signaling pathway of cardiac cells: (1) is mediated by isoprenaline and blocked by propranolol, (2) is prevented by PKA selective inhibitors and selective for L-type channels, (3) requires several minutes to reach maximal effects, (4) is voltage-independent and can be induced in cell-attached patch recordings by applying isoprenaline outside the patchpipette (see [17]). The presence of a cAMP/PKA-mediated pathway modulating the L-type channels of chromaffin cells represents a unique example of positive feedback signaling involved in the autocontrol of neurotransmitter release.

Unique is also the existence of two distinct $\beta_{1^{-}}$and $\beta_{2}$ AR activated signaling pathways in RCCs: one inhibiting and one potentiating the L-type channel gating [18]. The $\beta_{1}$-AR cascade acts by selectively up-regulating the L-type channel through a PKA-mediated pathway and develops slowly due to its diffusive characteristics. On the contrary, the $\beta_{2}$-AR signaling is fast and primarily coupled to PTX-sensitive $G$

(b)

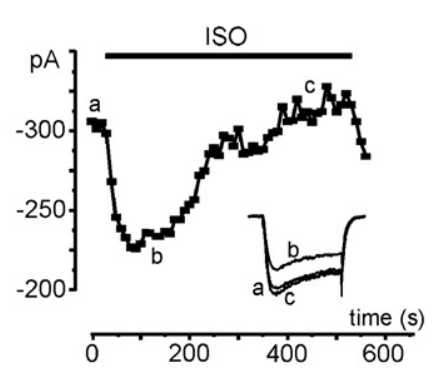

(d)

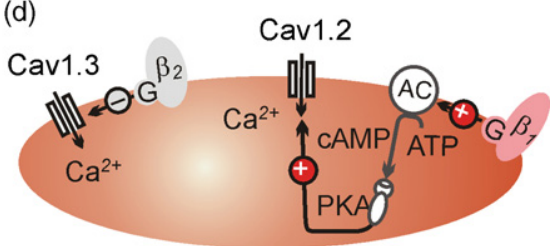

Fig. 1. Sequential inhibition and potentiation of L-type $\mathrm{Ca}^{2+}$ currents during $\beta_{2}$ - and $\beta_{1}$-ARs stimulation in RCCs. (A) Addition of isoprenaline (ISO) following the fast inhibition induced by zinterol (selective $\beta_{2}$-ARs agonist; $1 \mu \mathrm{M}$ ) induces a marked potentiation of L-type currents. The symbols are peak current amplitudes measured during a $25 \mathrm{~ms}$ step depolarization to $+10 \mathrm{mV}$ repeated every $10 \mathrm{~s}\left(V_{\mathrm{h}}-40 \mathrm{mV}\right)$. (B) Isoprenaline alone $(1 \mu \mathrm{M})$ causes a rapid inhibition and a slow recovery of L-type current amplitude. The insets show the original recordings taken at the time indicated. Modified from ref. [18]. (C) Schematic drawing of the signaling pathways in RCCs associated to $\beta_{1}$ - and $\beta_{2}$-ARs stimulation converging on the same channel type. (D) Same as in C but the two pathways are postulated to target Cav1.2 and Cav1.3 separately. 
proteins. Fig. 1a and b illustrated the experimental evidence supporting this interpretation. The sequential application of zinterol (a $\beta_{2}$-AR selective agonist) and isoprenaline (an unselective $\beta_{1} / \beta_{2}$-AR agonist) (Fig. $1 \mathrm{~A}$ ) nicely mimics the effects of isoprenaline alone (Fig. 1b), indicating that preliminary activation of $\beta_{2}$-ARs produces an inhibitory effect followed by a slow potentiation mediated by $\beta_{1}$-ARs. It is interesting to notice that the action of $\beta_{2}$-AR differs from that of $\beta_{1}$-AR mainly in the mode of action (Fig. 1c). $\beta_{2}$ ARs appear co-localized with $G$ proteins, adenylate cyclase, PKA-anchoring proteins and phosphatases, ensuring rapid activation or deactivation of specific signaling pathways (direct action) [49,50]. On the contrary, $\beta_{1}$-ARs stimulation preserves most of the prerequisites of $\beta_{1}$-AR stimulation of L-type channels in ventricular myocytes: it involves diffusible second messengers (cAMP and PKA), which phosphorylate the L-type $\mathrm{Ca}^{2+}$ channel (remote action).

\section{Two functionally active L-type channels in chromaffin cells?}

The schematic model of Fig. 1C assumes arbitrarily that the two opposing mechanisms mediated by $\beta_{1}$ and $\beta_{2}$-ARs converge on the same L-type channel but the alternative possibility that the two pathways target two distinct L-type channel isoforms cannot be excluded. RCCs and BCCs, are shown to express Cav1.2 and Cav1.3 channels [22-24] and thus the possibility that the direct inhibition by $\beta_{2}$-AR acts on Cav1.3 and the remote potentiation mediated by $\beta_{1}$-AR targets Cav1.2 (Fig. 1D) is an interesting possibility that needs to be verified. Indeed, the co-existence of two L-type channel isoforms in chromaffin cells, as shown in cardiac tissues, smooth muscles, $\beta$-pancreatic cells and sensory neurons (see [51]), raises three interesting questions concerning the role that the two channel isoforms play in the control of $\mathrm{Ca}^{2+}$. dependent processes in neuroendocrine cells. Do Cav1.2 and Cav1.3 control different cell functions? Could the modulation of Cav1.2 and Cav1.3 play a critical role in the up- or down-regulation of specific cellular functions? If so, can we obtain general molecular and biophysical information about these two channel types that can be used to understand their role in neurological and cardiovascular pathologies?

An answer to these questions would be easy if selective blockers for the two channel types would be available, but this is not the case. There are in fact no selective agonist or antagonists for the two channels available at the moment. Thus, the only reasonable alternative is an indirect approach using knockout mice for Cav1.2 and Cav1.3 channels [52,53] or mutated mice with inborn insensitivity to DHPs (Cav1.2DHP ${ }^{-/-}$) [54], which can furnish indirect information about the functional properties of $\mathrm{KO}$ or mutated channels. Comparing cell functions from wild type, $\mathrm{KO}$ or mutated mice can furnish precious information on the specific role that each channel isoform plays in a cell or groups of cells. Following this approach it has been possible to identify a critical role for Cav1.3 channels in heart beating [20] and in sensory transduction in cochlear hair cells [53] but also to exclude the contribution of Cav1.3 to insulin secretion in pancreatic $\beta$-cell [54].

Another useful approach which has furnished precious information about the two channel isoforms come from in vitro reconstituted cell functions using c-DNA recombinant channels co-expressed with $\beta$ and $\alpha_{2} \delta_{1}$ subunits [55,56]. From these studies it has become clear the sharply different voltage-range of activation between the two channel isoforms and other major gating differences. Briefly, the Cav1.3 isoform: (1) activates at $-20 \mathrm{mV}$ more negative potentials than the Cav1.2 type, (2) is characterized by fast activation kinetics and (3) is less sensitive to DHPs. It requires higher doses of DHPs to be fully blocked [56]. All this indicate that the Cav1.3 channel is a channel suitable for carrying inward currents during prolonged pace-making phases and in all cases to control $\mathrm{Ca}^{2+}$ entry at potentials close to resting. While the Cav1.2 isoform, which activates at more positive potentials, may be more appropriate for controlling $\mathrm{Ca}^{2+}$ entry during the early phase of action potential depolarization or during the falling phase of the action potentials.

\section{Evidence for a "low-threshold" L-type channel controlling RCCs excitability}

Cultured RCCs express both Cav1.2 and Cav1.3 isoforms but a selective separation of their biophysical properties has not yet been possible. There are however some clear indications that either one or both channels play a critical role in cell excitability, action potential firing and catecholamine secretion. The first evidence is illustrated in Fig. 2 and is related to the capability of L-type currents to activate at relatively low voltages $(-60$ to $-40 \mathrm{mV})$ and contribute up to $10 \%$ of the total $\mathrm{Ca}^{2+}$ current at these voltages (gray area in Fig. 2). For cells carrying on average $150 \mathrm{pA}$ at $0 \mathrm{mV}$ this implies that near resting potentials $(-54 \mathrm{mV})$ the L-type channels carry about $15 \mathrm{pA}$ of inward current that is capable of producing approximately $15-30 \mathrm{mV}$ depolarization when multiplied by the high input resistance of RCCs (1-2 G $\Omega$; Marcantoni et al. unpublished observation). Considering that L-type channels are slowly inactivating channels at physiological $\mathrm{Ca}^{2+}$ concentration ( $2 \mathrm{mM}$ ), the sustained L-type current would be able to charge the membrane capacitance and initiate the opening of $\mathrm{Na}^{+}$ and $\mathrm{Ca}^{2+}$ channels with activation threshold at $-35 \mathrm{mV}$. All this is in good agreement with the observation that L-type channels activate at potentials more negative than other neuronal and neuroendocrine HVA channels [57] and that part of the $I-V$ characteristics could result from the contribution of Cav1.3 channels that activate at potentials very negative $[19,56]$ and comparable to T-type channels. Reconstituted and wild-type Cav1.3 channels display activity that starts from very negative voltages and are involved in pace-making seno-atrial node cells [20] and controlling neu- 

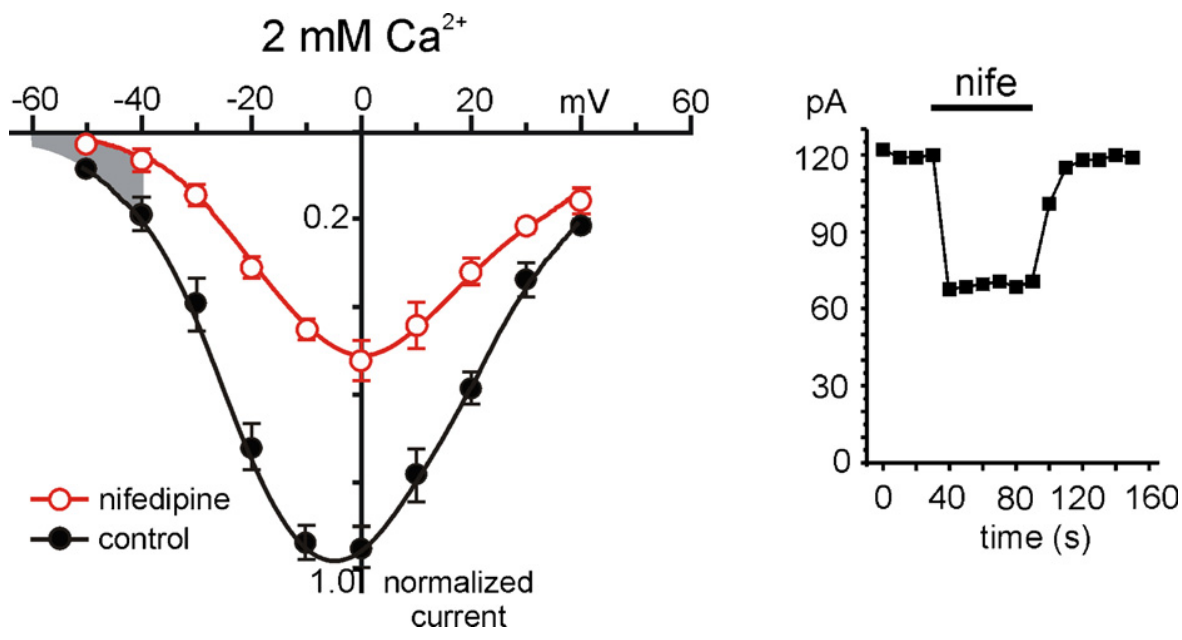

Fig. 2. Current-voltage $(I-V)$ relationship of $\mathrm{Ca}^{2+}$ currents recorded in the perforated-patch configuration from voltage-clamped RCCs in control conditions (filled circles, dark curve) and $3 \mu \mathrm{M}$ nifedipine (empty circles, red curve). The external $\mathrm{Ca}^{2+}$ concentration was $2 \mathrm{mM}$ (Tyrode standard solution) contained (mM): $130 \mathrm{NaCl}, 4 \mathrm{KCl}, 2 \mathrm{CaCl}_{2}, 2 \mathrm{MgCl}_{2}, 10 \mathrm{HEPES}, 10$ Glucose and the recording pipette contained (mM): $135 \mathrm{CsMeSO}_{3}, 8 \mathrm{NaCl}_{2} 20 \mathrm{Hepes}_{2} 2 \mathrm{MgCl}$. Pulses to the various voltages lasted $50 \mathrm{~ms}$ and were delivered at $10 \mathrm{~s}$ intervals from $-70 \mathrm{mV}$ holding potential. The dashed area between the two curves indicates the low-voltage region dominated by L-type channels that may originate the pace-maker current controlling the action potentials autorythmicity shown in Fig. 4a. Data are means \pm SEM from $n=15$ cells. To the right is shown the time course of peak current block by nifedipine $(3 \mu \mathrm{M})$ using pulses of $0 \mathrm{mV}$ delivered every $10 \mathrm{~s}$.

rotransmitter release in cochlear inner and outer hair cells $[53,58]$.

The second interesting evidence related to L-type channels in RCCs is their tight coupling to $\mathrm{Ca}^{2+}$-dependent $\mathrm{BK}$ channels that are highly expressed in BCCs and RCCs [25,59]. BK channels are responsible for the fast termination of action potential (after hyperpolarization) in these cells and force the action potential to quickly repolarize to about $-70 \mathrm{mV}$, thus allowing the fast deactivation and partial recruitment of inactivating $\mathrm{Na}^{+}$and $\mathrm{Ca}^{2+}$ channels that are responsible for the subsequent fast depolarization phase of the action potential. The BK channels of chromaffin cells have however a second interesting property. They possess a relatively fast and complete inactivation, which distinguishes them from the slow inactivating BK channels expressed in most other cells $[60,61]$.

Fig. 3a shows a typical time course of BK and voltagegated $\mathrm{K}^{+}$currents recorded during prolonged voltage-clamp depolarizations to $+80 \mathrm{mV}$, as they appear during a double pulse protocol normally used to separate them. In one case (no prepulse) the $\mathrm{K}^{+}$outward current is small, fast activating and hardly inactivating during the entire length of the pulse $\left(400 \mathrm{~ms}\right.$; red trace in Fig. 3a). Since little or no $\mathrm{Ca}^{2+}$ ions enter under these conditions, the recorded $\mathrm{K}^{+}$currents are mainly voltage-gated. In the second case (with the short prepulse to $0 \mathrm{mV}$ ) the outward current is nearly three to four times larger and fast inactivating. $\mathrm{Ca}^{2+}$ enters during the short prepulse and all the extra $\mathrm{K}^{+}$outward current recruited by the prepulse is thus associated to BK channels. They are blocked by saturating concentrations of $\mathrm{Cd}^{2+}$ (panel b) and by $1 \mu \mathrm{M}$ paxilline (panel c) that is a selective blocker of BK channels [62]. In addition, $3 \mu \mathrm{M}$ nifedipine produces a dramatic block of BK currents (panel d), confirming the findings of Chris
Lingle and collaborators that BK currents are tightly coupled to L-type channels.

\section{L-type channels control the firing frequency of spontaneously active RCCs}

BK currents play a crucial role in shaping the action potential repolarization phase and tuning the recruitment of $\mathrm{Na}^{+}$and $\mathrm{Ca}^{2+}$ channels that are responsible for the subsequent slow depolarization phase of spontaneously firing cells $[25,60]$. It is thus reasonable to believe that the tight coupling of L-type to BK channels is likely involved in the control of pace-maker activity in RCCs. Since RCCs express L-type channels that are already open at resting potentials (10\% at $-50 \mathrm{mV}$ in $2 \mathrm{mM} \mathrm{Ca}^{2+}$ ) (Fig. 2), it is evident that L-type channels can play the dual role of controlling the action potential shape by acting on BK channels and contribute to the pace-maker current that controls the firing frequency during spontaneous activity by opening at relatively low voltages. Fig. 4a shows an example of spontaneous activity recorded from a RCC in which L-type channels exert a marked effect on cell firing. Action potentials are recorded in current-clamp conditions using the perforated-patch configuration (see [63]). As shown, the cell is spontaneously active around a mean resting potential of $-50 \mathrm{mV}$ and fires regularly at a frequency of $1.3 \mathrm{impulses} / \mathrm{s}$, which is slightly slower than the mean frequency of these cells (1.9 impulses/s, $n=35$ cells; Marcantoni et al., unpublished results). The action potentials are characterized by a slow depolarizing phase that precedes the fast depolarization that leads to the maximal overshoot of about $+40 \mathrm{mV}$ (mean overshoot $+61.5 \mathrm{mV}$; $n=35$ cells) and then to the slower repolarizing phase to 
(a)

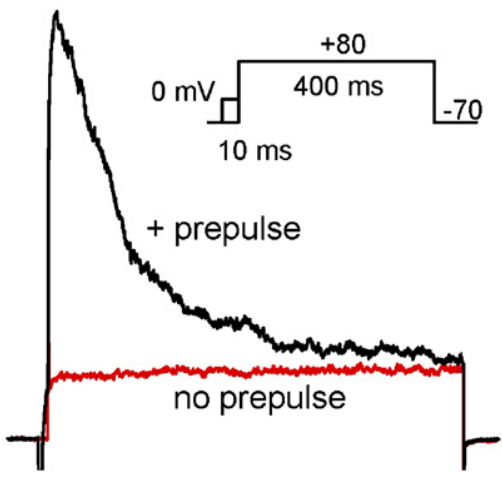

(c)

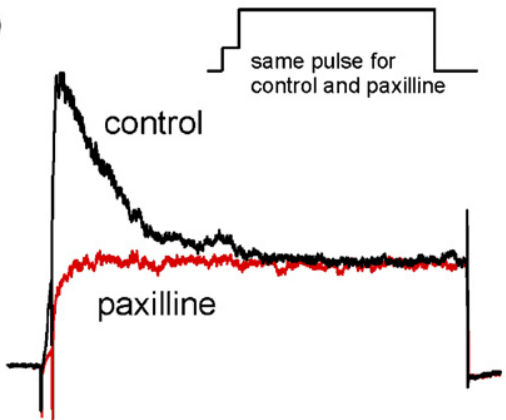

(b)

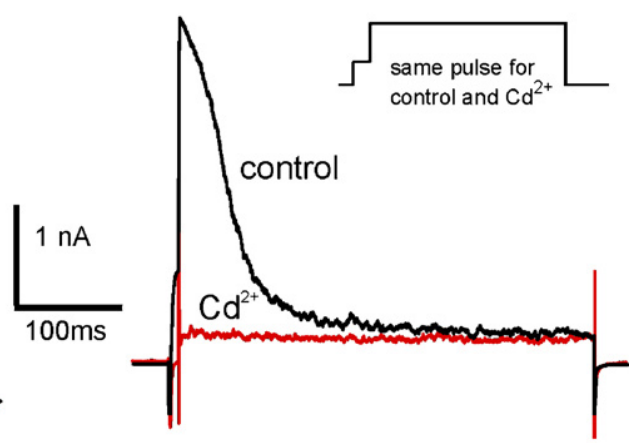

(d)

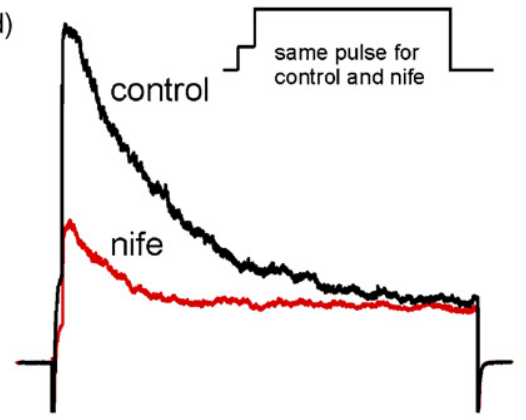

Fig. 3. $\mathrm{K}^{+}$and $\mathrm{Ca}^{2+}$ currents recorded in the perforated-patch configuration from four rat chromaffin cells. The pipette solution contained (mM): $135 \mathrm{KAsp}, 8$ $\mathrm{NaCl}, 20 \mathrm{Hepes}, 2 \mathrm{MgCl}_{2}, 5 \mathrm{EGTA}$. In order to inhibit sodium current the external Tyrode standard solution contained $300 \mathrm{nM}$ of TTX. In panel a, the voltage command consisted of a double pulse protocol in which the test potential of $400 \mathrm{~ms}$ to $+80 \mathrm{mV}$ was preceded or not by a short prepulse of $10 \mathrm{~ms}$ to $0 \mathrm{mV}$ to activate maximal inward $\mathrm{Ca}^{2+}$ currents that are not visible due to the extremely fast $\mathrm{BK}$ channel activation. The two pulses were separated by a $10 \mathrm{~s}$ interval. Notice the small noninactivating $\mathrm{K}^{+}$current recorded in the absence of prepulse (red trace) and the large fast inactivating outward current activated by $\mathrm{Ca}^{2+}$ entering during the prepulse (dark trace). In panels $b-d$ the voltage command consisted of a single pulse ( $10 \mathrm{~ms}$ prepulse to $0 \mathrm{mV}$ followed by a $400 \mathrm{~ms}$ test pulse to $+80 \mathrm{mV}$ ) delivered in control conditions (dark traces) and in the presence of $500 \mu \mathrm{M} \mathrm{Cd}^{2+}$ (b), $1 \mu \mathrm{M}$ paxilline (c) and $3 \mu \mathrm{M}$ nifedipine (d) (red traces). Notice how in all three conditions the BK current activated by the prepulse is strongly depressed by the three compounds.

$-64 \mathrm{mV}$ (mean undershoot $-63.5 \mathrm{mV} ; n=35$ cells). Addition of $1 \mu \mathrm{M}$ nifedipine causes nearly no changes to the rapid phase of depolarization but a net prolongation of action potential duration (between 1 and 10 times the mean duration at $-20 \mathrm{mV}, n=8$ cells) and the disappearance of the undershoot (red trace in panel b). This is exactly what would be expected if the BK channels coupled to L-type channels were no longer open. Besides affecting the shape of action potential, nifedipine clearly slows down the firing frequency (from 1.3 to $0.5 \mathrm{impulses} / \mathrm{s}$ ) with a further decrement to $0.3 \mathrm{impulses} / \mathrm{s}$ at $3 \mu \mathrm{M}$ concentration. In some cases high doses of nifedipine caused even a temporary block of action potential firing which partially recovered after wash out.

An interesting question related to the role that various $\mathrm{Ca}^{2+}$ channels play in the control of action potential generation in chromaffin cells is whether the autorythmicity of action potential firings observed in various cells occurs spontaneously $[64,65]$ or is the result of the current-clamp in whole-cell or perforated-patch recording conditions in which some uncontrolled inward current could drive the cell into a firing mode. To check this issue and test whether cultured RCCs possess an intrinsic firing activity at rest we recorded their electrical activity using an array of 60 metallic microelectrodes (MEA) connected to large bandwidth low-noise amplifiers designed for recording extracellular action potentials at high time resolution. Fig. 5a illustrates how microelectrodes are experimentally interfaced with the cells while panels $5 \mathrm{~b}$ and $5 \mathrm{c}$ show spontaneous extracellular recordings from different chromaffin cells. It is evident the autorhythmic activity that occurs in physiological condition, without any cell manipulation. Extracellular action potentials appear as fast downward deflections representing the negative first derivative of intracellularly recorded action potentials [66,67]. As shown, action potential firing occurs in bursts followed by brief interruptions as measured intracellularly using glass microelectrodes in the perforated-patch mode. To prove that $\mathrm{Ca}^{2+}$ channels activity was fully preserved under these conditions we blocked reversibly the firing by either removing the extracellular $\mathrm{Ca}^{2+}$ (replaced by $2 \mathrm{mM}$ $\mathrm{Mg}^{2+}$ ) (Fig. 5b) or adding $500 \mu \mathrm{M} \mathrm{Cd}^{2+}$ (Fig. 5c). Action potential activity was also blocked by adding $3 \mu \mathrm{M}$ TTX (not shown), while the firing frequency increased significantly by adding the nicotinic $\mathrm{ACh}$ analog acetyl-beta-methylcholine $(100 \mu \mathrm{M})$, as observed in previous recordings [68]. Under these conditions we also tested whether the modulatory action of nifedipine illustrated in Fig. 4 was preserved in intact autorythmic chromaffin cells. Panel 5d shows that indeed this is the case. Three micromolars of nifedipine produced 


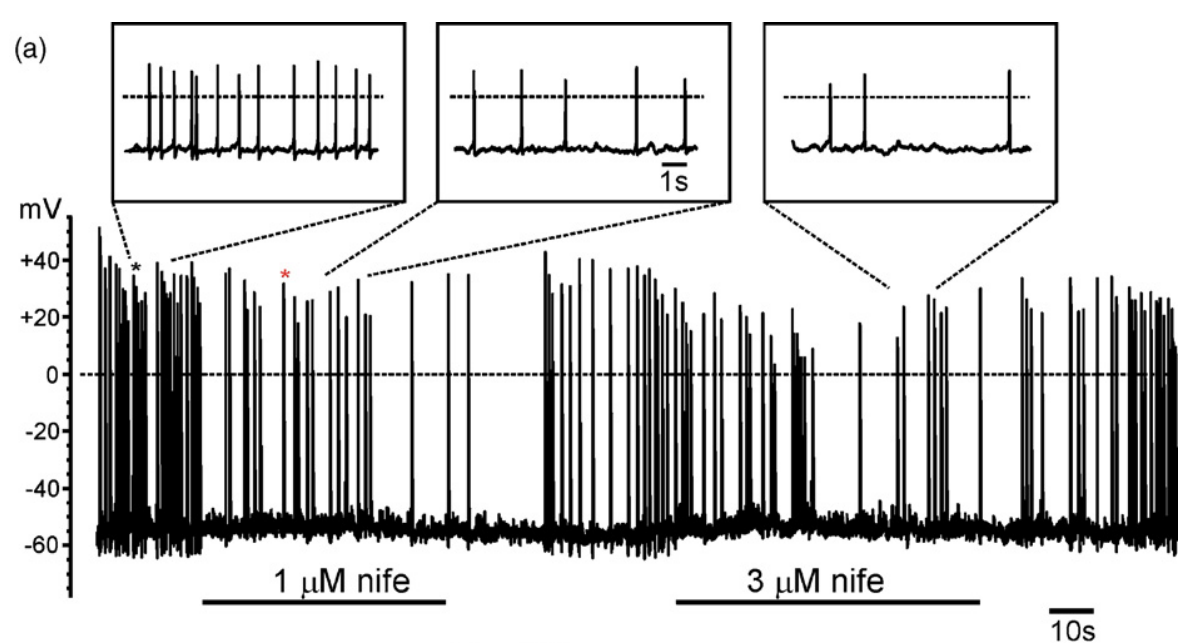

(b)

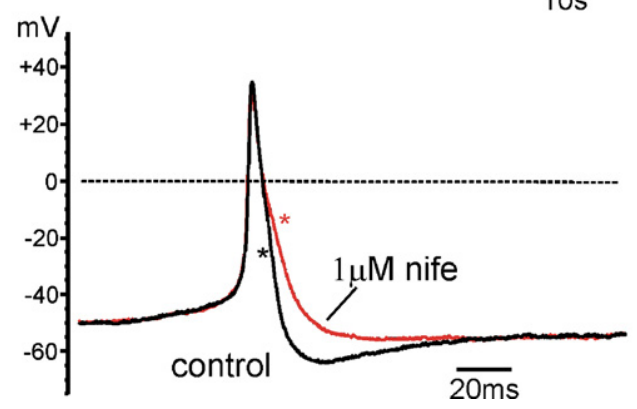

Fig. 4. Spontaneous action potential activity recorded from a rat chromaffin cell in the perforated-patch configuration. The current-clamp recording was achieved by holding the cell at rest without passing current. Data were acquired at $10 \mathrm{kHz}$ and filtered at $1 \mathrm{kHz}$. The horizontal bars indicate the period of nifedipine application. Panel a shows the full recordings of action potentials while panel $b$ shows on an expanded time scale two overlapped action potentials recorded at the time indicated by the asterisks in panel a. The action potential shape with $3 \mu \mathrm{M}$ nifedipine was similar to that with $1 \mu \mathrm{M}$. The three boxes above the original recordings show on an expanded time scale $10 \mathrm{~s}$ of recordings at control and in the presence of 1 and $3 \mu \mathrm{M}$ nifedipine. The pipette solution was the same used in the experiments of Fig. 3 and the external solution was the Tyrode standard.

a slowing-down of action potential firing and removed the fast repolarizing phase (upward deflection of control trace) associated with the block of BK channels coupled to L-type channels. To our knowledge those illustrated in Fig. 5 are the first reported extracellular action potential recordings using MEAs in chromaffin cells.

The results of Figs. 4 and 5 are in good agreement with the idea that L-type channels activating at relatively low voltages can indeed control the amount of inward current required for driving the cell from resting potential $(\sim-50 \mathrm{mV})$ to the threshold of $\mathrm{Na}^{+}$and $\mathrm{Ca}^{2+}$ channel opening which is set around $-35 \mathrm{mV}$ in $2 \mathrm{mM} \mathrm{Ca}^{2+}$. Notice that to induce a $15 \mathrm{mV}$ depolarization in a resting chromaffin cell with an access resistance of 1.5-2 G $\Omega$ are necessary only 7.5-10 pA that can be easily obtained for prolonged periods of time by the open L-type channels expressed in RCCs. In fact these channels possess two important features to the purpose: (1) they activate at relatively low-voltages (gray area in Fig. 2) and inactivate very little at low holding potentials $(-40$, $-50 \mathrm{mV}$ ), ensuring their availability for prolonged periods of times at low voltages. The results of Fig. 4 reinforce the idea that the L-type (in particular the Cav1.3 isoform) are the $\mathrm{Ca}^{2+}$ channels that are potentially able to control the firing rate of neurons and cardiac cells because of their low- threshold of activation [20,69,70]. Future experiments using action potential-clamps and specific pharmacological dissections of inward and outward currents contributing to the shape of action potentials will allow to determine more precisely the role and contribution of L-type channels to the electrically activity of chromaffin cells. It is also evident that such task is crucial for accurately understanding the role of L-type channels in the regulation of catecholamine release at different physiological conditions.

\section{L-type channels and fast exocytosis in chromaffin cells}

As discussed in recent reviews [11,23,71,72] chromaffin cells express different densities of high-voltage and lowvoltage-activated $\mathrm{Ca}^{2+}$ channels. Their coexistence at the plasma membrane raises the question of whether all these channel types participate to the control of exocytosis and how their density of expression and gating properties affect their contribution. In addition, the proportion of various $\mathrm{Ca}^{2+}$ channels varies widely between animal species and, thus, catecholamine secretion is controlled differently, depending on the $\mathrm{Ca}^{2+}$ channel types more highly expressed. Concerning 
(a)

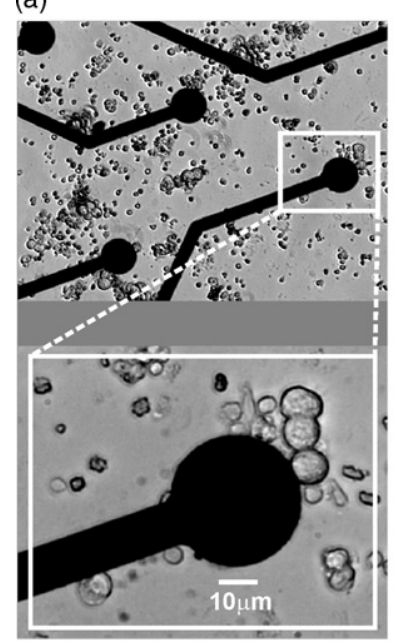

(b)

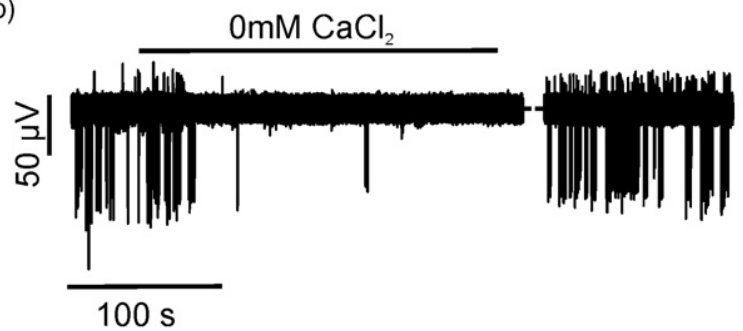

(c)

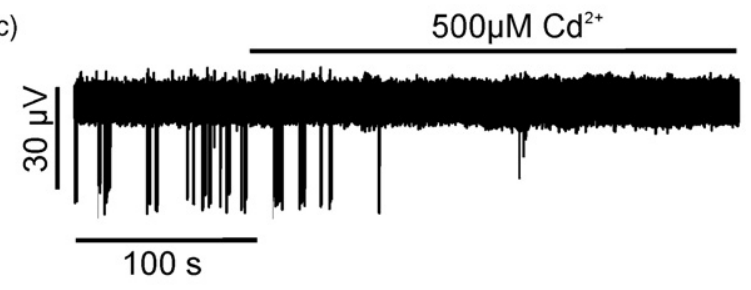

(d)

$3 \mu \mathrm{M}$ nifedipine

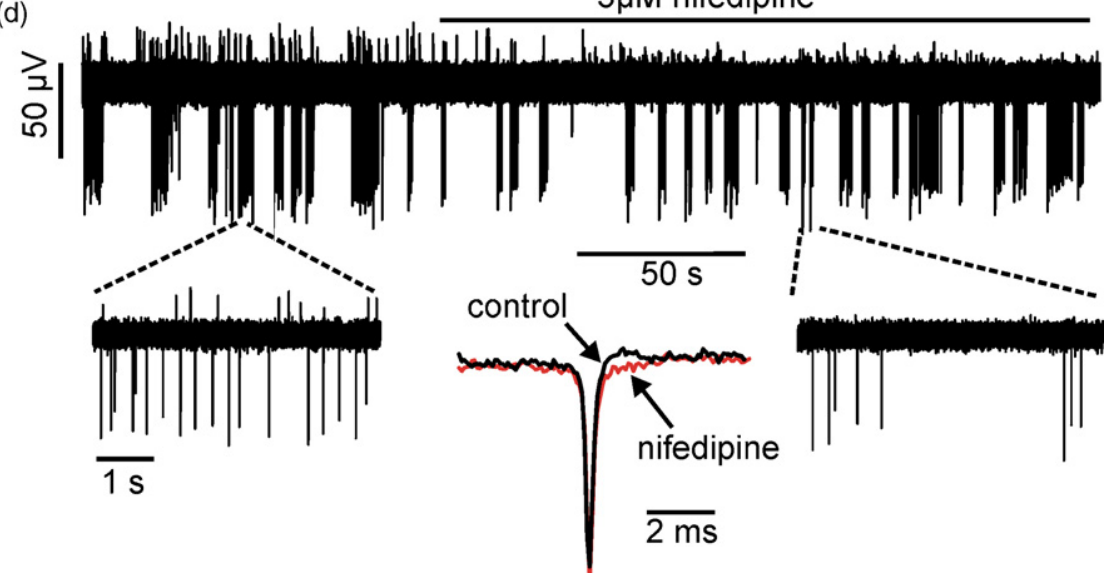

Fig. 5. Spontaneous activity in rat chromaffin cells recorded with a multi-electrode array (MEA). (a) Photomicrograph of RCCs plated on a multielectrode array (MEA1060, Multi Channel Systems GmbH, Reuttlingen, Germany) for simultaneous recording of extracellular action potentials from 60 metallic microelectrodes (diameter: $30 \mu \mathrm{m}$ ). (b) Spontaneous action potentials recorded with MEA and reversibly blocked by replacing the external $\mathrm{Ca}^{2+}$ with $2 \mathrm{mM}$ $\mathrm{Mg}^{2+}$. During the experiments, cells were kept at $37^{\circ} \mathrm{C}$ and perfused with the Tyrode standard solution. (c) Extracellular recording of spontaneous action potentials inhibited in the presence of $500 \mu \mathrm{M} \mathrm{Cd}^{2+}$. (d) Spontaneous action potentials partially inhibited by nifedipine $(3 \mu \mathrm{M})$. The inhibition of L-type channels mainly affect the repolarizing phase, as illustrated in the inset showing the average of 30 single synchronized action potentials recorded both in control condition (dark trace) and in the presence of nifedipine (red trace). The data from the 60 channels were acquired at $10 \mathrm{kHz}$ and not filtered.

the role that L-type channels play in the control of exocytosis there is wide consensus to the idea that they are critically linked to secretion in all animal species, even in the bovine cells in which L-type channels are minimally expressed $[73,74]$. So far, L-type channels are shown to control catecholamine secretion in human, bovine, rat, mouse and cat chromaffin cells independently of the kind of stimulus used (KCl- and ACh-induced depolarization, electrical field stimulation, voltage step depolarizations and action potential trains), type of technique (capacitance changes, amperometry, chemical, radioactive and optical detections) and type of cell preparation (cultured cells, adrenal gland slices or intact perfused adrenal gland). Here we will focus on the most relevant findings related to the role that L-type channels play in the release of catecholamine considering the limitations that a particular methodology used may introduce in detecting the secretion.
Looking carefully at all the data reported on $\mathrm{Ca}^{2+}$ channels-secretion coupling [11] appears evident that whenever are used "strong stimuli" (prolonged depolarization with high $\mathrm{KCl}$ solutions, sustained applications of $\mathrm{ACh}$ or repeated strong depolarizations), the contribution of L-type channels to secretion overwhelms the proportion of $\mathrm{Ca}^{2+}$ currents that these channels control in each cell preparation. L-type channels predominate the secretion despite their contribution to the total current in single cell experiments is partial or very small, as in the case of BCCs [73,74]. A dominance of L-type channel-mediated secretion is thus reported in bovine [4,75-77], mouse [78,79], rat [9,10,80,81] and cat chromaffin cells $[82,83]$ more or less independently of whether intact adrenal glands or cultured chromaffin cells are used. The reason for this general finding is that during prolonged depolarization (far from physiological conditions) L-type channels are probably more favored because of their 
slower time-dependent inactivation and lower steady-state inactivation with respect to the other HVA channels (P/Q, $\mathrm{N}$ and $\mathrm{R}$ ), which inactivate more rapidly and completely during prolonged stimuli. However, when evaluated under voltage-clamp conditions using capacitance changes on single cells, the contribution of L-type channels appear reduced and strictly proportional to the quantity of $\mathrm{Ca}^{2+}$ charges carried. Compared to the others (N, P/Q and R), the Ltype channel has the same $\mathrm{Ca}^{2+}$-efficiency and contributes proportionally to their density of expression on the plasma membrane. These effects are observed in bovine [84-86], rat [80,81] and mouse [79] chromaffin cells with the exception of adrenal mouse slices in which secretion appears predominated by R-type channels [87]. Thus, most of the available data favor the idea that unlike presynaptic terminals in which $\mathrm{N}$ and P/Q-type channels are highly co-localized to the active zone of neurotransmitter release, in chromaffin cells there is no preferential co-localization of any particular $\mathrm{Ca}^{2+}$ channel type. In chromaffin cells the maximal rate of vesicle release is estimated around 500 vesicles/s $[88,89]$ while in presynaptic terminals the rate of release can be as high as 300 vesicles/ms [90]. These different functional conditions demand for markedly different geometrical arrangements of secretory vesicles and $\mathrm{Ca}^{2+}$ channels for the two systems. In one case, the rapid rise of $\mathrm{Ca}^{2+}$ near the presynaptic active zone is achieved through a high co-localization of vesicles and $\mathrm{Ca}^{2+}$ channels. Alternatively, in the case of chromaffin cells, the slower rise of $\mathrm{Ca}^{2+}$ near the secretory granules is achieved through a homogeneous distribution of $\mathrm{Ca}^{2+}$ channels located at some distance from the secretory zone.

\section{7. $\mathrm{Ca}^{2+}$ channels-secretion coupling in chromaffin cells}

A generally accepted model of $\mathrm{Ca}^{2+}$ channels and vesicle distribution in chromaffin cells assumes that vesicles are colocalized in microscopic domains distributed all over the cell with $\mathrm{Ca}^{2+}$ channels uniformly distributed [42] and located at an average distance of $200 \mathrm{~nm}$, i.e., at a distance comparable to the vesicle size [91], (Klinghauf-Neher model). According to this model all $\mathrm{Ca}^{2+}$ channel types are more or less uniformly distributed at the secretory sites and contribute to secretion proportionally to their density of expression. Secretion is strictly dependent on the quantity of $\mathrm{Ca}^{2+}$ charge entering the cells independently of the type of channel open, length of pulse and voltage amplitude producing the current [84]. This applies also to the T-type channels that are recruited during long-term incubations with cAMP [89] or chronic exposure to hypoxic conditions (Carabelli et al., unpublished observation). A rigorous comparison of T- and L-type channel properties shows that, although operating at different potentials and with different voltage-sensitivity, the two channels possess otherwise similar $\mathrm{Ca}^{2+}$-dependence of exocytosis, size of the immediately releasable pool and mobilize vesicles of the same quantal size. Thus, T- and L-type channels are coupled with the same $\mathrm{Ca}^{2+}$-efficiency to the secretory apparatus and deplete the immediately releasable pool with the same rate of release $[92,93]$.

If the Klinghauf-Neher model explains most of the data obtained with capacitance changes using square pulse commands, some data escape this rule [87] and there is also evidence of $\mathrm{Ca}^{2+}$ channels co-localization with vesicle secretion, which require consideration (see [11] for a detailed review on the subject). In addition, there are critical issues that are not yet properly considered and that deserve particular attention. One among the many is the shape of the stimuli used in the capacitance technique, which can be critical to identify the role of each channel type. Chan et al. [79] have recently reported that in mouse adrenal slices, the contribution of HVA channels to total secretion changes remarkably if square pulses or action potential-like stimuli are used. In the first case the L-type channels seem to predominate while in the second case the P/Q-types appear as the main channels controlling secretion. The reason for this is attributed to the different gating properties of the two channels rather than to a specific co-localization of one type with respect to the other. P/Q-type channels activate more quickly during a brief action potential clamp and thus reach peak currents sooner than more slowly activating L-type currents. This is significantly different from applying long square pulse of 50-100 $\mathrm{ms}$ in which all channels open and reach steady state values of currents at time intervals that are far beyond the physiological range. The work of Chan et al., however makes use of mocked action potentials made with rising and falling ramp waves, which are different from the real time course of spontaneous action potentials recorded from autorythmic chromaffin cells (see Fig. 4b). This may cause some alteration to the overall $\mathrm{Ca}^{2+}$ currents contributing to secretion. For instance a slow depolarizing phase of $200-300 \mathrm{~ms}$ from -50 to $-35 \mathrm{mV}$ preceding the fast action potential is capable of driving significant amount of $\mathrm{Ca}^{2+}$ ions through L-type channels, which therefore will contribute critically to the secretion of catecholamine. The type and shape of the stimulus is so critical that trains of increasing frequency may recover functional L-type channels to a state of enhanced stimulus-secretion efficiency in mouse adrenal slices [94].

It is thus very important that future approaches focusing on the role of different $\mathrm{Ca}^{2+}$ channels play in the control of catecholamine secretion make use of biological preparations and type of stimulus that are as much as possible close to the physiological conditions, mimicking resting as well as sustained activity of the adrenal gland.

\section{Conclusions}

The importance of L-type channels in the control of chromaffin cell excitability and catecholamine secretion is now well documented and increases progressively meanwhile new experiments become available. The contribution of L-type channels appears critical in the control of action poten- 
tials frequency in spontaneously firing cells and this may result in an even more critical role in the overall control of catecholamine secretion. L-type channels are also effectively modulated by the same neurotransmitters released by chromaffin cells (autocrine modulation). This creates a further degree of complication but open-up interesting lines of research directed to the distinct involvement of multiple Ltype channel isoforms (Cav1.2 and Cav1.3), which hopefully could be solved by using knockout and mutated mice for the two channel isoforms. Concerning the coupling of L-type channel to secretory vesicles, at present there are no specific requirements for having L-type or any other $\mathrm{Ca}^{2+}$ channels strictly co-localized to the secretory sites but improved measurements of $\mathrm{Ca}^{2+}$ currents and secretion will help clarifying better also this issue.

\section{Acknowledgments}

This work was supported by the Italian MIUR (grants COFIN No. 2005054435 to EC), the Regione Piemonte (grants No. A28-2005 to VC and No. D14-2005 to EC), the San Paolo IMI Foundation (grant to the NIS Center of Excellence), the European Research Training Network CavNET and by a Ramon y Cajal contract and grant 2004/07998 to JM H-G.

\section{References}

[1] W.A. Catterall, E. Perez-Reyez, T.P. Snutch, J. Striessnig, International union of pharmacology. XLVIII. Nomenclature and structure-function relationships of voltage-gated calcium channels, Pharmacol. Rev. 57 (4) (2005) 411-425.

[2] F. Hofmann, L. Lacinová, N. Klugbauer, Voltage-dependent calcium channels: from structure to function, Rev. Physiol. Biochem. Pharmacol. 139 (1999) 33-87.

[3] W.A. Catterall, Structure and regulation of voltage-gated $\mathrm{Ca}^{2+}$ channels, Annu. Rev. Cell. Dev. Biol. 16 (2000) 521-555.

[4] A.G. García, F. Sala, J.A. Reig, S. Viniegra, J. Frías, R.I. Fonteriz, L. Gandía, Dihydropyridine Bay-K-8644 activates chromaffin cell calcium channels, Nature 309 (1984) 69-71.

[5] N.C. Spitzer, P.A. Kingston, T.J. Manning, M.W. Conklin, Outside and in: development of neuronal excitability, Curr. Opin. Neurobiol. 12 (2002) 315-323.

[6] V. Schulla, E. Renstrom, R. Feil, S. Feil, I. Franklin, A. Gjinovci, X.J. Jing, D. Laux, I. Lundquist, M.A. Magnuson, S. Obermuller, C.S. Olofsson, A. Salehi, A. Wendt, N. Klugbauer, C.B. Wollheim, P. Rorsman, F. Hofmann, Impaired insulin secretion and glucose tolerance in beta cell-selective Ca(v)1.2 Ca2+ channel null mice, EMBO J. 22 (2003) 3844-3854.

[7] S.N. Yang, P.O. Berggren, The role of voltage-gated calcium channels in pancreatic beta-cell physiology and pathophysiology, Endocr. Rev. 27 (2006) 621-676.

[8] S. Sedej, T. Tsujimoto, R. Zorec, M. Rupnik, Voltage-activated $\mathrm{Ca}^{2+}$ channels and their role in the endocrine function of the pituitary gland in newborn and adult mice, J. Physiol. 555 (2004) 769-782.

[9] T. Nagayama, T. Matsumoto, F. Kuwakubo, Y. Fukushima, M. Yoshida, M. Suzuki-Kusaba, H. Hisa, T. Kimura, S. Satoh, Role of calcium channels in catecholamine secretion in the rat adrenal gland, J. Physiol. 520 (1999) 503-512.
[10] T. Akiyama, T. Yamazaki, H. Mori, K. Sunagawa, Effects of $\mathrm{Ca}^{2+}$ channel antagonists on acetylcholine and catecholamine releases in the in vivo rat adrenal medulla, Am. J. Physiol. Regul. Integr. Comp. Physiol. 287 (1) (2004) R161-R166.

[11] A.G. Garcia, A.M. Garcia-De-Diego, L. Gandia, R. Borges, J. GarciaSancho, Calcium signalling and exocytosis in adrenal chromaffin cells, Physiol. Rev. 86 (2006) 1093-1131.

[12] K.N. Green, J.P. Boyle, C.J. Peers, Hypoxia potentiates exocytosis and $\mathrm{Ca}^{2+}$ channels in PC12 cells via increased amyloid $\beta$-peptide formation and reactive oxygen species generation, J. Physiol. 541 (2002) 1013-1023.

[13] P. Baldelli, P.E. Forni, E. Carbone, BDNF, NT-3 and NGF induce distinct new $\mathrm{Ca}^{2+}$ channel synthesis in developing hippocampal neurons, Eur. J. Neurosci. 12 (2000) 4017-4032.

[14] N. Lalevee, M.C. Rebsamen, S. Barrere-Lemaire, E. Perrier, J. Nargeot, J.P. Benitah, M.F. Rossier, Aldosterone increases T-type calcium channel expression and in vitro beating frequency in neonatal rat cardiomyocytes, Cardiovasc. Res. 67 (2005) 216-224.

[15] J.M. Hernández-Guijo, V. Carabelli, L. Gandía, A.G. García, E. Carbone, Voltage-independent autocrine modulation of L-type channels mediated by ATP, opioids and catecholamines in rat chromaffin cells, Eur. J. Neurosci. 11 (1999) 3574-3584.

[16] A.C. Dolphin, L-type calcium channel modulation, Adv. Second Messenger Phosphoprotein Res. 33 (1999) 153-170.

[17] E. Carbone, V. Carabelli, T. Cesetti, P. Baldelli, J.M. HernándezGuijo, L. Giusta, G-protein- and cAMP-dependent L-channel gating modulation: a manyfold system to control calcium entry in neurosecretory cells, Pflügers Arch. -Eur. J. Physiol. 442 (2001) 801813.

[18] T. Cesetti, J.M. Hernandez-Gujio, P. Baldelli, V. Carabelli, E. Carbone, Opposite action of beta 1 - and beta 2 -adrenergic receptors on $\mathrm{Ca}(\mathrm{V}) 1 \mathrm{~L}$ channel current in rat adrenal chromaffin cells, J. Neurosci. 23 (2003) 73-83.

[19] D. Lipscombe, T.D. Helton, W. Xu, L-type calcium channels: the low down, J. Neurophysiol. 92 (2004) 2633-2641.

[20] M.E. Mangoni, B. Couette, E. Bourinet, J. Platzer, D. Reimer, J. Striessnig, J. Nargeot, Functional role of L-type $\mathrm{Ca}_{\mathrm{v}} 1.3 \mathrm{Ca}^{2+}$ channels in cardiac pacemaker activity, Proc. Natl. Acad. Sci. U.S.A. 100 (2003) 5543-5548.

[21] E. García-Palomero, I. Cuchillo, A.G. García, J. Renart, A. Albillos, C. Montiel, Greater diversity than previously thought of chromaffin cell $\mathrm{Ca}^{2+}$ channels, derived from mRNA identification studies, FEBS Lett. 481 (2000) 235-239.

[22] E. García-Palomero, J. Renart, E. Andrés-Mateos, L.M. Solís, C. Matute, C.J. Herrero, A.G. García, A. Albillos, C. Montiel, Differential expression of calcium channels subtypes in the bovine adrenal medulla, Neuroendocrinology 74 (2001) 251-261.

[23] P. Baldelli, J.M. Hernandez-Guijo, V. Carabelli, M. Novara, T. Cesetti, E. Andres-Mateos, C. Montiel, E. Carbone, Direct and remote modulation of L-channels in chromaffin cells: distinct actions on alpha1C and alpha1D subunits? Mol Neurobiol. 29 (2004) 73-96.

[24] A. Benavides, S. Calvo, D. Tornero, C. Gonzalez-Garcia, V. Cena, Adrenal medulla calcium channel population is not conserved in bovine chromaffin cells in culture, Neuroscience 128 (2004) 99-109.

[25] M. Prakriya, C.J. Lingle, BK channel activation by brief depolarizations requires $\mathrm{Ca}^{2+}$ influx through $\mathrm{L}$ - and Q-type $\mathrm{Ca}^{2+}$ channels in rat chromaffin cells, J. Neurophysiol. 8 (1999) 2267-2278.

[26] A. Muller, M. Kukley, M. Uebachs, H. Beck, D. Dietrich, Nanodomains of single $\mathrm{Ca}^{2+}$ channels contribute to action potential repolarization in cortical neurons, J. Neurosci. 27 (2007) 483-495.

[27] Y.B. Park, J. Herrington, D.F. Babcock, B. Hille, $\mathrm{Ca}^{2+}$ clearance mechanisms in isolated rat adrenal chromaffin cells, J. Physiol. 492 (1996) 329-346.

[28] J.M. Hernandez-Guijo, V.E. Maneu-Flores, A. Ruiz-Nuno, M. Villarroya, A.G. Garcia, L. Gandia, Calcium-dependent inhibition of L, N, and $\mathrm{P} / \mathrm{Q} \mathrm{Ca}^{2+}$ channels in chromaffin cells: role of mitochondria, $\mathrm{J}$. Neurosci. 21 (2001) 2553-2560. 
[29] D. Pietrobon, P. Hess, Novel mechanism of voltage-dependent gating in L-type calcium channels, Nature 346 (1990) 651-655.

[30] T. Hoshi, J. Rothlein, S.J. Smith, Facilitation of $\mathrm{Ca}^{2+}$-channel currents in bovine adrenal chromaffin cells, Proc. Natl. Acad. Sci. U.S.A. 81 (1984) 5871-5875.

[31] E.T. Kavalali, M.R. Plummer, Multiple voltage-dependent mechanisms potentiate calcium channel activity in hippocampal neurons, J. Neurosci. 16 (1996) 1072-1082.

[32] C.R. Artalejo, S. Rossie, R.A. Perlman, A.P. Fox, Voltage-dependent phosphorylation may recruit $\mathrm{Ca}^{2+}$ current facilitation in chromaffin cells, Nature 358 (1992) 63-66.

[33] A. Sculptoreanu, T. Scheuer, W. Catterall, Voltage-dependent potentiation of L-type $\mathrm{Ca}^{2+}$ channels due to phosphorylation by cAMPdependent protein kinase, Nature 364 (1993) 240-243.

[34] B.D. Johnson, J.P. Brousal, B.Z. Peterson, P.A. Gallombardo, G.H. Hockerman, Y. Lai, T. Scheuer, W.A. Catterall, Modulation of the cloned skeletal muscle L-type $\mathrm{Ca}^{2+}$-channel by anchored cAMP-dependent protein kinase, J. Neurosci. 17 (1997) 1243 1255.

[35] P.C. Gray, V.C. Tibbs, W.A. Catterall, B.J. Murphy, Identification of a 15-kDa cAMP-dependent protein kinase-anchoring protein associated with skeletal muscle L-type calcium channels, J. Biol. Chem. 272 (1997) 6297-6302.

[36] D.H. Cox, K. Dunlap, Pharmacological discrimination of N-type from L-type $\mathrm{Ca}^{2+}$ current and its selective modulation by neurotransmitters, J. Neurosci. 12 (1992) 906-914.

[37] I.M. Mintz, B.P. Bean, GABAB receptor inhibition of P-type $\mathrm{Ca}^{2+}$ channels in central neurons, Neuron 10 (1993) 889-898.

[38] E. Sher, P. Cesare, A. Codignola, F. Clementi, P. Tarroni, A. Pollo, V. Magnelli, E. Carbone, Activation of $\delta$-opioid receptors inhibits neuronal-like calcium channels and distal steps of $\mathrm{Ca}^{2+}$-dependent secretion in human small-cell lung carcinoma cells, J. Neurosci. 16 (1996) 3672-3684.

[39] A. Albillos, E. Carbone, L. Gandía, A.G. García, A. Pollo, Opioid inhibition of $\mathrm{Ca}^{2+}$ channel subtypes in bovine chromaffin cells: selectivity of action and voltage-dependence, Eur. J. Neurosci. 8 (1996) $1561-1570$.

[40] V. Carabelli, J.M. Hernández-Guijo, P. Baldelli, E. Carbone, Direct autocrine inhibition and cAMP-dependent potentiation of single L-type $\mathrm{Ca}^{2+}$ channels in bovine chromaffin cells, J. Physiol. 532 (1) (2001) 73-90.

[41] L. Liu, R. Zhao, Y. Bai, L.F. Stanish, J.E. Evans, M.J. Sanderson, J.V. Bonventre, A.R. Rittenhouse, M1 muscarinic receptors inhibit L-type $\mathrm{Ca}^{2+}$ current and $\mathrm{M}$-current by divergent signal transduction cascades, J. Neurosci. 26 (2006) 11588-11598.

[42] V. Carabelli, I. Carra, E. Carbone, Localized secretion of ATP and opioids revealed through single $\mathrm{Ca}^{2+}$ channel modulation in bovine chromaffin cells, Neuron 20 (1998) 1255-1268.

[43] B.P. Bean, M.C. Nowycky, R.W. Tsien, $\beta$-Adrenergic modulation of calcium channels in frog ventricular heart cells, Nature 307 (1984) 371-375.

[44] H. Reuter, Calcium channel modulation by neurotransmitters, enzymes and drugs, Nature 301 (1983) 569-574.

[45] H.C. Hartzell, P.F. Mery, R. Fischmeister, G. Szabo, Sympathetic regulation of cardiac calcium current is due exclusively to cAMP-dependent phosphorylation, Nature 351 (1991) 573-576.

[46] E.T. Kawalali, K.S. Hwang, M.R. Plummer, cAMP-dependent enhancement of dihydropyridine-sensitive calcium channel availability in hippocampal neurons, J. Neurosci. 17 (1997) 5334-5348.

[47] J.C. Henquin, H.P. Meissner, The ionic, electrical and secretory effects of endogeneous cyclic adenosine monophosphate in mouse pancreatic $\beta$ cells: studies with forskolin, Endocrinology 115 (1984) 11251134.

[48] C. Ämmälä, F.M. Ashcroft, P. Rorsman, Cyclic AMP-dependent potentiation of exocytosis in insulin secreting pancreatic $\beta$-cells by stimulation of calcium-influx and direct interaction with the secretory machinery, Nature 363 (1993) 356-358.
[49] R.P. Xiao, X. Ji, E.G. Lakatta, Functional coupling of the $\beta_{2}$ adrenoceptor to a pertussis toxin-sensitive $G$ protein in cardiac myocytes, Mol. Pharmacol. 47 (1995) 322-329.

[50] R.P. Xiao, P. Avdonin, Y.Y. Zhou, H. Cheng, S.A. Akhter, T. Eschenhagen, R.J. Lefkowitz, W.J. Koch, E.G. Lakatta, Coupling of $\beta_{2}$-adrenoceptor to Gi protein and its physiological relevance in murine cardiac myocytes, Circ. Res. 84 (1999) 43-52.

[51] J. Striessnig, A. Koschak, M.J. Sinnegger-Brauns, A. Hetzenauer, N.K. Nguyen, P. Busquet, G. Pelster, N. Singewald, Role of voltage-gated $\mathrm{L}$-type $\mathrm{Ca}^{2+}$ channel isoforms for brain function, Biochem. Soc. Trans. 34 (2006) 903-909.

[52] C. Seisenberger, V. Specht, A. Welling, J. Platzer, A. Pfeifer, S. Kuhbandner, J. Striessnig, N. Klugbauer, R. Feil, F. Hofmann, Functional embryonic cardiomyocytes after disruption of the L-type alpha1C (Cav1.2) calcium channel gene in the mouse, J. Biol. Chem. 275 (50) (2000) 39193-39199.

[53] J. Platzer, J. Engel, A. Schrott-Fischer, K. Stephan, S. Bova, H. Chen, H. Zheng, J. Striessnig, Congenital deafness and sinoatrial node dysfunction in mice lacking class D L-type $\mathrm{Ca}^{2+}$ channels, Cell 102 (2000) 89-97.

[54] M.J. Sinnegger-Brauns, A. Hetzenauer, I.G. Huber, E. Renstrom, G. Wietzorrek, S. Berjukov, M. Cavalli, D. Walter, A. Koschak, R. Waldschutz, S. Hering, S. Bova, P. Rorsman, O. Pongs, N. Singewald, J. Striessnig, Isoform-specific regulation of mood behavior and pancreatic beta cell and cardiovascular function by L-type $\mathrm{Ca}^{2+}$ channels, $\mathrm{J}$. Clin. Invest. 113 (2004) 1430-1439.

[55] W. Xu, D. Lipscombe, Neuronal Ca(V)1.3alpha(1) L-type channels activate at relatively hyperpolarized membrane potentials and are incompletely inhibited by dihydropyridines, J. Neurosci. 21 (2001) 5944-5951.

[56] T.D. Helton, W. Xu, D. Lipscombe, Neuronal L-type calcium channels open quickly and are inhibited slowly, J. Neurosci. 25 (2005) 10247-10251.

[57] A. Pollo, M. Lovallo, E. Biancardi, E. Sher, C. Socci, E. Carbone, Sensitivity to dihydropyridines, omega-conotoxin and noradrenaline reveals multiple high-voltage-activated $\mathrm{Ca}^{2+}$ channels in rat insulinoma and human pancreatic beta-cells, Pflugers Arch. 423 (1993) 462-471.

[58] M. Michna, M. Knirsch, J.C. Hoda, S. Muenkner, P. Langer, J. Platzer, J. Striessnig, J. Engel, Cav1.3 (alpha1D) $\mathrm{Ca}^{2+}$ currents in neonatal outer hair cells of mice, J. Physiol. 553 (2003) 747-758.

[59] A. Marty, Ca-dependent $\mathrm{K}$ channels with large unitary conductance in chromaffin cell membranes, Nature 291 (1981) 497-500.

[60] C.R. Solaro, M. Prakriya, J.P. Ding, C.J. Lingle, Inactivating and noninactivating $\mathrm{Ca}^{2+}$ - and voltage-dependent $\mathrm{K}^{+}$current in rat adrenal chromaffin cells, J. Neurosci. 15 (1995) 6110-6123.

[61] P. Orio, P. Rojas, G. Ferreira, R. Latorre, New disguises for an old channel: MaxiK channel beta-subunits, News Physiol. Sci. 17 (2002) $156-161$.

[62] V.K. Gribkoff, J.T. Lum-Ragan, C.G. Boissard, D.G. Post-Munson, N.A. Meanwell, J.E. Starrett Jr., E.S. Kozlowski, J.L. Romie, J.T. Trojnacki, M.C. McKay, J. Zhong, S.I. Dworetzky, Effects of channel modulators on cloned large-conductance calcium-activated potassium channels, Mol. Pharmacol. 50 (1996) 206-217.

[63] M. Novara, P. Baldelli, D. Cavallari, V. Carabelli, A. Giancippoli, E. Carbone, Exposure to cAMP and beta-adrenergic stimulation recruits $\mathrm{Ca}_{\mathrm{v}} 3$ T-type channels in rat chromaffin cells through Epac cAMPreceptor proteins, J. Physiol. 558 (2004) 433-449.

[64] D.J. Wallace, C. Chen, P.D. Marley, Histamine promotes excitability in bovine adrenal chromaffin cells by inhibiting an M-current, J. Physiol. 540 (2002) 921-939.

[65] F. Gullo, E. Ales, B. Rosati, M. Lecchi, A. Masi, L. Guasti, M.F Cano-Abad, A. Arcangeli, M.G. Lopez, E. Wanke, ERG K ${ }^{+}$channel blockade enhances firing and epinephrine secretion in rat chromaffin cells: the missing link to LQT2-related sudden death? FASEB J. 17 (2003) 330-332.

[66] D.A. Henze, Z. Borhegyi, J. Csicsvari, A. Mamiya, K.D. Harris, G. Buzsăki, Intracellular features predicted by extracellular record- 
ings in the hippocampus in vivo, J. Neurophysiol. 84 (2000) 390400 .

[67] A. Stett, U. Egert, E. Guenther, F. Hofmann, T. Meyer, W. Nisch, $\mathrm{H}$. Haemmerle, Biological application of microelectrode arrays in drug discovery and basic research, Anal. Bioanal. Chem. 377 (2003) 486-495.

[68] A. Akaike, Y. Mine, M. Sasa, S. Takaori, Voltage and current clamp studies of muscarinic and nicotinic excitation of the rat adrenal chromaffin cells, J. Pharmacol. Exp. Therap. 255 (1990) 333-339.

[69] C.F. Hsiao, C.A. Del Negro, P.R. Trueblood, S.H. Chandler, Ionic basis for serotonin-induced bistable membrane properties in guinea pig trigeminal motoneurons, J. Neurophysiol. 79 (1988) 28472856.

[70] D.C. Cooper, F.J. White, L-type calcium channels modulate glutamatedriven bursting activity in the nucleus accumbens in vivo, Brain Res. 880 (2000) 212-218.

[71] I. Cuchillo-Ibanez, A. Albillos, M.S. Aldea, G. Arroyo, J. Fuentealba, A.G. Garcia, Calcium entry, calcium redistribution, and exocytosis, Ann. N.Y. Acad. Sci. 971 (2002) 108-116.

[72] E. Carbone, A. Giancippoli, A. Marcantoni, D. Guido, V. Carabelli, A new role for T-type channels in fast "low-threshold" exocytosis, Cell Calcium 40 (2006) 147-154.

[73] J.L. Bossu, M. De Waard, A. Feltz, Two types of calcium channels are expressed in adult bovine chromaffin cells, J. Physiol. 437 (1991) 621-634.

[74] L. Gandia, A. Albillos, A.G. Garcia, Bovine chromaffin cells possess FTX-sensitive calcium channels, Biochem. Biophys. Res. Commun. 194 (1993) 671-676.

[75] P.J. Owen, D.B. Marriott, M.R. Boarder, Evidence for a dihydropyridine-sensitive and conotoxin-insensitive release of noradrenaline and uptake of calcium in adrenal chromaffin cells, Br. J. Pharmacol. 97 (1989) 133-138.

[76] M.G. Lopez, M. Villarroya, B. Lara, R. Martinez Sierra, A. Albillos, A.G. Garcia, L. Gandia, Q- and L-type $\mathrm{Ca}^{2+}$ channels dominate the control of secretion in bovine chromaffin cells, FEBS Lett. 349 (1994) 331-337.

[77] B. Lara, L. Gandia, R. Martinez-Sierra, A. Torres, A.G. Garcia, Q-type $\mathrm{Ca}^{2+}$ channels are located closer to secretory sites than L-type channels: functional evidence in chromaffin cells, Pflugers Arch. Eur. J. Physiol. 435 (1998) 472-478

[78] M. Aldea, K. Jun, H.S. Shin, E. Andres-Mateos, L.M. Solis-Garrido, C. Montiel, A.G. Garcia, A. Albillos, A perforated patchclamp study of calcium currents and exocytosis in chromaffin cells of wild-type and alpha(1A) knockout mice, J. Neurochem. 81 (2002) 911-921.

[79] S.A. Chan, L. Polo-Parada, C. Smith, Action potential stimulation reveals an increased role for P/Q-calcium channel-dependent exocytosis in mouse adrenal tissue slices, Arch. Biochem. Biophys. 435 (1) (2005) 65-73.
[80] S.J. Kim, W. Lim, J. Kim, Contribution of L- and N-type calcium currents to exocytosis in rat adrenal medullary chromaffin cells, Brain Res. 675 (1995) 289-296.

[81] V. Carabelli, A. Giancippoli, P. Baldelli, E. Carbone, A.R. Artalejo, Distinct potentiation of L-type currents and secretion by cAMP in rat chromaffin cells, Biophys. J. 85 (2003) 1326-1337.

[82] A.M. Cardenas, C. Montiel, C. Esteban, R. Borges, A.G. Garcia, Secretion from adrenaline- and noradrenaline-storing adrenomedullary cells is regulated by a common dihydropyridine-sensitive calcium channel, Brain Res. 456 (1988) 364-366.

[83] M.G. Lopez, A. Albillos, M.T. de la Fuente, R. Borges, L. Gandia, E. Carbone, A.G. Garcia, A.R. Artalejo, Localized L-type calcium channels control exocytosis in cat chromaffin cells, Pflugers Arch. 427 (1994) 348-354.

[84] K.L. Engisch, M.C. Nowycky, Calcium dependence of large densecored vesicle exocytosis evoked by calcium influx in bovine adrenal chromaffin cells, J. Neurosci. 16 (1996) 1359-1369.

[85] E.A. Lukyanetz, E. Neher, Different types of calcium channels and secretion from bovine chromaffin cells, Eur. J. Neurosci. 11 (1999) 2865-2873.

[86] R. Thiagarajan, T. Tewolde, Y. Li, P.L. Becker, M.M. Rich, K.L. Engisch, Rab3A negatively regulates activity-dependent modulation of exocytosis in bovine adrenal chromaffin cells, J. Physiol. 555 (2004) 439-457.

[87] A. Albillos, E. Neher, T. Moser, R-type $\mathrm{Ca}^{2+}$ channels are coupled to the rapid component of secretion in mouse adrenal slice chromaffin cells, J. Neurosci. 20 (2000) 8323-8330.

[88] F.T. Horrigan, R.J. Bookman, Releasable pools and the kinetics of exocytosis in adrenal chromaffin cells, Neuron 13 (1994) 1119-1129.

[89] A. Giancippoli, M. Novara, A. de Luca, P. Baldelli, A. Marcantoni, E. Carbone, V. Carabelli, Low-threshold exocytosis induced by cAMPrecruited $\mathrm{Ca}_{\mathrm{v}} 3.2\left(\alpha_{1 \mathrm{H}}\right)$ channels in rat chromaffin cells, Biophys. J. 90 (2006) 1830-1841.

[90] R. Schneggenburger, E. Neher, Presynaptic calcium and control of vesicle fusion, Curr. Opin. Neurobiol. 15 (3) (2005) 266-274.

[91] J. Klingauf, E. Neher, Modeling buffered $\mathrm{Ca}^{2+}$ diffusion near the membrane: implications for secretion in neuroendocrine cells, Biophys. J. 72 (1997) 674-690.

[92] E. Carbone, A. Marcantoni, A. Giancippoli, D. Guido, V. Carabelli, T-type channels-secretion coupling: evidence for a fast low-threshold exocytosis, Pflügers Archiv. 453 (2006) 373-383.

[93] V. Carabelli, A. Marcantoni, V. Comunanza, E. Carbone, Fast exocytosis mediated by T- and L-type channels in chromaffin cells: distinct voltage-dependence but similar $\mathrm{Ca}^{2+}$-dependence, European Biophys. J., doi:10.1007/s00249-007-0138-2, in press.

[94] L. Polo-Parada, S.A. Chan, C. Smith, An activity-dependent increased role for L-type calcium channels in exocytosis is regulated by adrenergic signaling in chromaffin cells, Neuroscience 143 (2006) 445-459. 